\title{
Eucalyptus wood and coffee parchment for particleboard production: Physical and mechanical properties
}

\section{Madeira de eucalipto e pergaminho de café na produção de aglomerados: Propriedades físicas e mecânicas}

\author{
Mário Vanoli Scatolino ${ }^{1 *}$, Andrey de Oliveira Costaㄹㄹ , José Benedito Guimarães Júnior ${ }^{3}$, \\ Thiago de Paula Protásio ${ }^{3}$, Rafael Farinassi Mendes ${ }^{3}$, Lourival Marin Mendes ${ }^{3}$
}

'Universidade Federal de Lavras/UFLA, Departamento de Ciências Florestais/DCF, Lavras, MG, Brasil

2Universidade Federal de Goiás/UFG, Jataí, GO, Brasil

${ }^{3}$ Universidade Federal de Lavras/UFLA, Lavras, MG, Brasil

*Corresponding author: marioufla@posgrad.ufla.br

Received in October 2, 2016 and approved in December 6, 2016

\begin{abstract}
The wood panel industry is constantly growing, being necessary the innovation in technologies and raw materials to improve the quality of the final product. Considering the shortage and pressure to decrease the dependence of wood, there is an interest in other renewable materials such as agricultural wastes. Among these wastes, coffee parchment is one which deserves notoriety. An alternative use for coffee parchment could be for production of particleboard in association with wood particles. This study aimed to evaluate the feasibility of using coffee parchment for production of particleboard. The following percentages of wastes were used: $0,10,20,30,40$ and $50 \%$ in association to eucalyptus wood. The panels were produced with $8 \%$ of urea formaldehyde (based on dry weight of particles). The pressing cycle consisted by: pre-pressing of $0.5 \mathrm{MPa}$ for 10 minutes followed by pressing of $4.0 \mathrm{MPa}$, and temperature of $160^{\circ} \mathrm{C}$ for 15 minutes. The compaction ratio of particleboards produced using higher quantities of parchment improved the physical properties. The properties of Water Absorption ( 2 and $24 \mathrm{~h}$ ) and Thickness Swelling ( $2 \mathrm{~h}$ ) decreased with increasing percentage of coffee parchment. The Thickness Swelling (24 h) showed not significant effect with an increase of coffee waste. The Modulus of Elasticity for coffee parchment particleboards was in the range $646.49 \pm 112.65$ to $402.03 \pm 66.24 \mathrm{MPa}$, while the Modulus of Rupture ranged from $8.18 \pm 1.39$ to $4.45 \pm$ $0.75 \mathrm{MPa}$. The results showed that $10 \%$ of coffee parchment could be added for production of particleboards.
\end{abstract}

Index terms: Agricultural waste; lignocellulosic material; renewable material.

\begin{abstract}
RESUMO
A indústria de painéis de madeira vem em constante crescimento, sendo necessária a inovação em tecnologias e matéria-prima para melhorar a qualidade do produto final. Considerando a escassez e pressão na diminuição da dependência por madeira, existe um interesse em outros materiais renováveis, como os resíduos agrícolas. Entre esses resíduos, o pergaminho de café merece destaque. Uma alternativa para utilização do pergaminho de café poderia ser na produção de particulados, em associação com partículas de madeira. O objetivo deste trabalho foi avaliar a viabilidade de utilização do pergaminho de café para produção de aglomerados. As porcentagens de resíduo utilizadas foram: 0, 10, 20, 30, 40 e 50\% em associação com madeira de eucalipto. Os painéis foram produzidos com $8 \%$ de uréia-formaldeído (base massa seca de partículas). 0 ciclo de prensagem consistiu de: pré-prensagem de $0,5 \mathrm{MPa}$ por 10 minutos, seguido por prensagem de 4,0 MPa e temperatura de $160^{\circ} \mathrm{C}$ por 15 minutos. A razão de compactação dos painéis produzidos com maiores quantidades de pergaminho melhorou as propriedades físicas. As propriedades de absorção de água ( 2 e 24 h) e inchamento em espessura ( 2 h) diminuíram com o aumento da porcentagem de pergaminho de café. $\mathrm{O}$ inchamento em espessura ( $24 \mathrm{~h}$ ) não apresentou diferenças significativas com o aumento de resíduo de café. O Módulo de Elasticidade dos painéis variou de 646,49 $\pm 112,65$ até 402,03 $\pm 66,24 \mathrm{MPa}$, enquanto o Módulo de Ruptura variou de 8,18 \pm 1,39 até 4,45 \pm 0,75 MPa. Os resultados mostraram que até $10 \%$ de pergaminho de café poderia ser adicionados para a produção de painéis aglomerados.
\end{abstract}

Termos para indexação: Resíduos agrícolas; materiais lignocelulósicos; material renovável.

\section{INTRODUCTION}

The brazilian industry of particleboards consumes a significant volume of wood from planted forests, mainly from Eucalyptus genera. Such species get emphasize due to the good adaptation in a large area of Brazilian territory and availability for exploring (Mendes et al., 2014).
However, the growth of the sector becomes necessary to search for other lignocellulosic materials sources that may contribute to supply the needs of industries as well as contribute to the development of new products (Belini et al., 2014; Farrapo et al., 2014). Considering the growing concern about the environment and the pressure 
to decrease the wood dependence, the forestry industry seeks new substitute materials hence there is an interest in renewable materials, such as agricultural wastes generated by several crops as sugar cane, rice husk, corn and coffee, which is one of the most important in Brazil.

In 2013, the Brazilian production of coffee (green grain) was approximately $3,000,000 \mathrm{t}$, which ranks the country as the greatest world producer of coffee (FAO, 2013). One of the wastes obtained from this culture is the coffee parchment, a byproduct which is usually discarded after the grain processing. The parchment, known as "thin rind" for being an anatomical pellicle which covers the grain, is part of the waste generated by the coffee processing obtained when the pulping occurs by wet method (Brum et al., 2008). According to Vilela et al. (2001), coffee processing results in wastes such as husk and parchment, which yield approximately $50 \%$. Therefore, the processing of two tons of coffee produces a ton of waste. After the grain processing, the main destination given to the coffee parchment is the briquettes and pellets production for burning and energy generation (Paula et al., 2011). An environmentallyfriendly alternative for the coffee parchment destination could be for particleboards production.

The production of particleboards from agricultural wastes adds value to the residue, reducing the impact on the environment, furthermore, it can meet the growing demand for wood panels, enable the expansion, decrease the use of wood in the production process, the pressure on forests, while reducing production costs of the panels (Mendes et al., 2010).

Abundantly available plants cultivated in agriculture might be good candidates, showing also anatomical and chemical structures suitable to produce panels (Mati-Baouche et al., 2014; Papadopoulou et al., 2015). Different researchers have reported the utilization of agricultural wastes in particleboards production, such as sugarcane bagasse (Mendes et al., 2012), rice husk (Melo et al., 2009), maize cob (Scatolino et al., 2013; Scatolino et al., 2015; Sekaluvu; Tumutegyereize; Kiggundu, 2014), coffee husk (Mendes et al., 2010), peanut husk (Guler; Buyuksari 2011), corn straw (Silva et al., 2015), vine (Vitis vinifera L.) (Yeniocak et al., 2014) and castor husk (Silva et al., 2016).

In addition, many studies in the literature show the mixture of agricultural wastes with wood species. Mendes et al. (2010) evaluated the influence of coffee husks in association to Eucalyptus urophylla in the physical and mechanical properties of particleboard. Similarly, Silva et al. (2016) studied the association of castor husk and Pinus oocarpa wood for production of particleboard.

The coffee parchment could be a potential alternative material for being applied in particleboards production, due the fact of being basically composed by cellulose and lignin, such as wood. The aim of this study was to evaluate the potential of using coffee parchment as raw material for particleboard production associated with eucalyptus wood considering the physical and mechanical properties.

\section{MATERIAL AND METHODS}

\section{Raw material and particle processing}

The coffee parchments were provided by a cooperative company located in the district of Machado, Minas Gerais State, Brazil. The eucalyptus was a Eucalyptus urophylla $\mathrm{x}$ Eucalyptus grandis hybrid collected from a dense crop located in the campus of Federal University of Goiás, in Jataí, Goiás State, Brazil. 36 months-old eucalyptus trees were used in this study. The eucalyptus wood was subjected to analysis for determining basic density values according to procedures in standard NBR 11941 (ABNT, 2003a).

The basic density of coffee parchment was obtained by saturation of particles and subsequent volume measurement in a measuring cylinder. The particles were then dried and the relation dry weight/saturated volume was calculated. The wood particles were obtained by crushing of small logs through a Kawashima Tg 1400-s (100 mm) mill. Posteriorly, the particles were crushed again through a mill containing a $6 \mathrm{~mm}$ sieve. Coffee parchment was separated from the grain processing impurities and crushed through a mill. The particles were sieved and the fraction that was retained between the $20(0.841 \mathrm{~mm})$ and 40 mesh $(0.420 \mathrm{~mm})$ were used for production of particleboards.

\section{Chemical analysis of materials}

For analysis of the chemical components of eucalyptus and coffee parchment, the sawdust retained between the $40(0.420 \mathrm{~mm})$ and $60(0.250 \mathrm{~mm})$ mesh sieves was used. The material was subjected to analysis for determining the total extractives content - NBR 14853 (ABNT, 2010a), lignin content - NBR 7989 (ABNT, 2010b), minerals content - NBR 13999 (ABNT, 2003b) and holocellulose content (obtained by the difference $\mathrm{H}(\%)$ $=100-\%$ Total extractives - \%Lignin content - \%Ashes content). 


\section{Experimental design and production of particleboards}

The experimental design consisted of six treatments (Table 1), which five percentages of coffee parchment were used in replacement of eucalyptus.

Table 1: Experimental design for particleboard production.

\begin{tabular}{ccc}
\hline Type & Coffee parchment & Eucalyptus wood \\
\hline 1 & 0 & 100 \\
2 & 10 & 90 \\
3 & 20 & 80 \\
4 & 30 & 70 \\
5 & 40 & 60 \\
6 & 50 & 50 \\
\hline
\end{tabular}

The panels were produced with dimensions of $200 \times 200 \times 15 \mathrm{~mm}$ (length, width and thickness, respectively). The level of urea-formaldehyde (UF) adhesive was $8 \%$ (based on dry weight of particles). The properties of UF were: solid content $66.07 \%, \mathrm{pH}$ 8.94 and viscosity $479 \mathrm{cP}$. The particles were manually added to adhesive. The mixture was placed into a sheet mold and pre-pressed at $0.5 \mathrm{MPa}$ during 10 minutes. The resulting sheet was then subjected to a hot compression cycle at temperature of $160^{\circ} \mathrm{C}$, pressure of $4 \mathrm{MPa}$ for 15 minutes. Two panels were produced for each treatment.

\section{Evaluation of panels and statistical analysis}

Once panels were acclimatized at a temperature of $22 \pm 2{ }^{\circ} \mathrm{C}$ and $65 \pm 5 \%$ of relative humidity, test samples were obtained using a circular saw. The compaction ratio was obtained by applying the following equation:

$$
C R=\frac{p d}{c p d x(c p \%)+e w d x(e w \%)}
$$

where: $p d$ is the particleboard apparent density $\left(\mathrm{g} / \mathrm{cm}^{3}\right)$; $c p d$ is the basic density of coffee parchment $\left(\mathrm{g} / \mathrm{cm}^{3}\right) ; c p \%$ is the content of coffee parchment; ewd is the basic density of eucalyptus wood $\left(\mathrm{g} / \mathrm{cm}^{3}\right)$; and $e w \%$ is the content of eucalyptus wood.

Analyses of the properties Water Absorption after two and twenty-four hours of immersion (WA2h and WA24h), Thickness Swelling after two and twenty- four hours of immersion (TS2h and TS24h) and Internal Bond (IB) were based on standard American Society for Testing and Materials - ASTM - D1037 (2006), while analyses of the properties Modulus of Rupture (MOR) and Modulus of Elasticity (MOE) were based on standard DIN 52362 (1982).

The experiment used a completely randomized design. As the objective of this study was to verify variations in results of physical and mechanical properties as a function of increasing coffee parchment percentage, data were subjected to ANOVA and analysis of regression, both at 5\% significance level.

\section{RESULTS AND DISCUSSION}

\section{Characterization of lignocellulosic materials and particleboards}

The contents of extractives, lignin, minerals and holocellulose in wood and coffee waste were listed in Table 2 . The lignin content was very similar for both materials, in the range from 27.27 to $28.32 \%$. Lignin is responsible for providing mechanical and biological resistance, and has hydrophobic properties necessary for the functioning of the conductive water cell (Neutelings, 2011).

The higher content of extractives in parchment in comparison to wood was considerable, in range from 3.59 to $26.24 \%$. Extractives are hydrophobic compounds of low molecular weight which can occur in minimal or significant levels and depend of the species and geographical location of plants (Hardell; Nilvebrant, 1999). Higher values of extractives in lignocellulosic raw materials are related to decreased permeability and hygroscopicity of the material (Iwakiri, 2005). Other agricultural wastes reported in literature also showed extractives content much lower than the coffee parchment. Scatolino et al. (2013) found $7.0 \%$ for extractives when studying maize cob chemical composition. Oppositely, Silva et al. (2016) found values of $30.1 \%$, which were according to the waste studied in this research.

The hygroscopicity of the extractives found in coffee parchment in addition to higher compaction ratio of particleboards with higher content of waste (Table 3 ) could be a crucial factors for reducing the WA2h and WA24h values (Figures 1 and 2). Another factor which may have contributed to the improvement of the physical properties is the lower value holocellulose presented by the waste, which indicates a lower value of hemicelluloses. 
Table 2: Chemical composition of the studied materials and some lignocellulosic biomass.

\begin{tabular}{ccccc}
\hline \multirow{2}{*}{ Material } & Extractives & Ashes & Lignin & Holocellulose \\
\cline { 2 - 5 } & & - & - & \\
\hline Eucalyptus wood & $3.59 \pm 0.09 *$ & $0.51 \pm 0.01$ & $27.27 \pm 1.69$ & $68.62 \pm 1.59$ \\
Coffee parchment & $26.24 \pm 1.71$ & $0.57 \pm 0.09$ & $28.32 \pm 0.76$ & $44.86 \pm 0.83$ \\
\hline
\end{tabular}

*Standard deviations of the means.

Table 3: Mean apparent density and compaction ratio of panels.

\begin{tabular}{ccc}
\hline Coffee parchment (\%) & Apparent density $\left(\mathrm{g} / \mathrm{cm}^{3}\right)$ & Compaction Ratio \\
\hline 0 & $0.54 \pm 0.03^{*} \mathrm{a}$ & $1.30 \pm 0.07 \mathrm{a}$ \\
10 & $0.54 \pm 0.02 \mathrm{a}$ & $1.32 \pm 0.05 \mathrm{a}$ \\
20 & $0.50 \pm 0.01 \mathrm{a}$ & $1.33 \pm 0.05 \mathrm{a}$ \\
30 & $0.53 \pm 0.02 \mathrm{a}$ & $1.53 \pm 0.06 \mathrm{~b}$ \\
40 & $0.54 \pm 0.01 \mathrm{a}$ & $1.73 \pm 0.05 \mathrm{c}$ \\
50 & $0.52 \pm 0.00 \mathrm{a}$ & $1.91 \pm 0.04 \mathrm{~d}$ \\
\hline
\end{tabular}

*Standard deviations of the means.

Different letters indicate significant $(p \leq 0.05)$ differences between the values by comparison using Scott-Knott test.

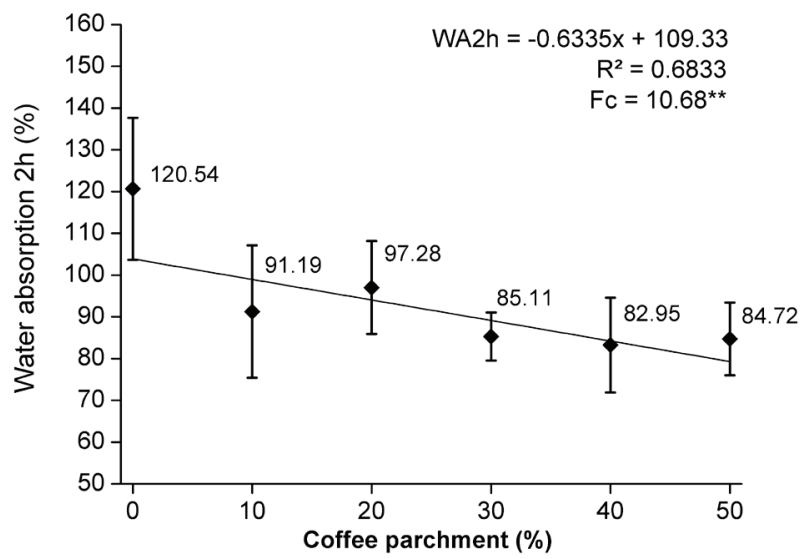

Figure 1: Mean values of WA2h as a function of coffee parchment percentage.

**Significant F-value at 5\% significance level.

In both cases, there was a trend of reduction in WA values with the addition of coffee parchment in particleboards. This was assumed to be due to the higher extractives amount present in coffee parchment, which may have increased the hydrophobic characteristics of the particleboards produced with the addition of the waste. The board composed by $0 \%$ of coffee parchment, in other hand, showed less resistance against the water penetration and showed the highest WA values. Mendes et al. (2010) also found an increasing tendency for water absorption after twenty-four hours of immersion when evaluating particleboard panels produced with coffee husk in association with eucalyptus. Boards produced in the same range of density from cotton stalks are reported to show $83.8 \%$ and $105.4 \%$ for WA2h and WA24h, respectively (Guler and Ozen, 2004). The apparent densities of particleboards in this study ranged from 0.50 to $0.54 \mathrm{~g} / \mathrm{cm}^{3}$, which rank them as low density particleboards (until $0.55 \mathrm{~g} / \mathrm{cm}^{3}$ ) according to NBR 14810 (ABNT, 2013).

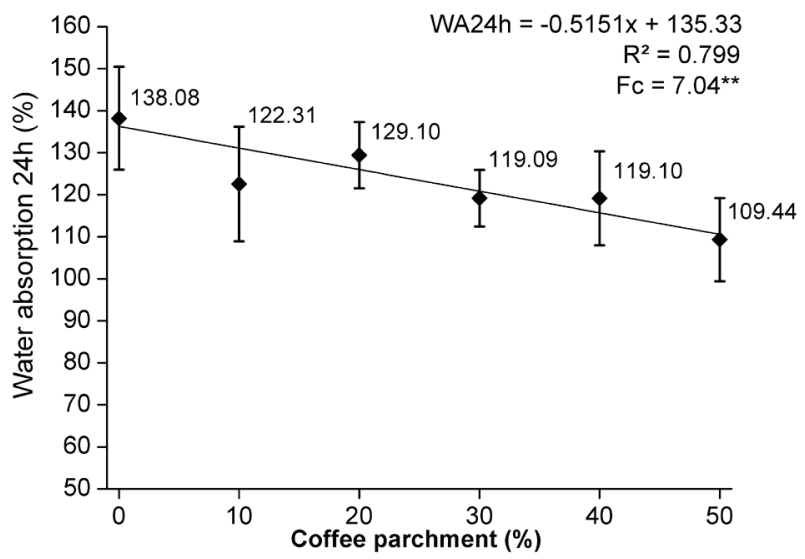

Figure 2: Mean values of WA24h as a function of coffee parchment percentage.

**Significant F-value at 5\% significance level. 
An increase in coffee parchment content of particleboards resulted in higher compaction ratio values. This fact may be certainly explained by the low value of basic density found for coffee parchment $(0.100 \mathrm{~g} /$ $\left.\mathrm{cm}^{3}\right)$ in comparison to eucalyptus wood $\left(0.450 \mathrm{~g} / \mathrm{cm}^{3}\right)$. Low density is one of requirements in intention to use lignocellulosic materials for particleboards production. It results in higher number of particles compressed in the same volume thus increasing the compression ratio (Iwakiri, 2005). Only the treatments composed by 0 to $30 \%$ coffee parchment (not statistically different) and $40 \%$ were according to the ideal values of compaction ratio (1.3 to 1.6) indicated by Maloney (1993).

The higher values for compaction ratio obtained by the other treatments may have affected the other physical properties. The plots of TS2h and TS24h versus coffee parchment content levels are shown in Figures 3 and 4, respectively.

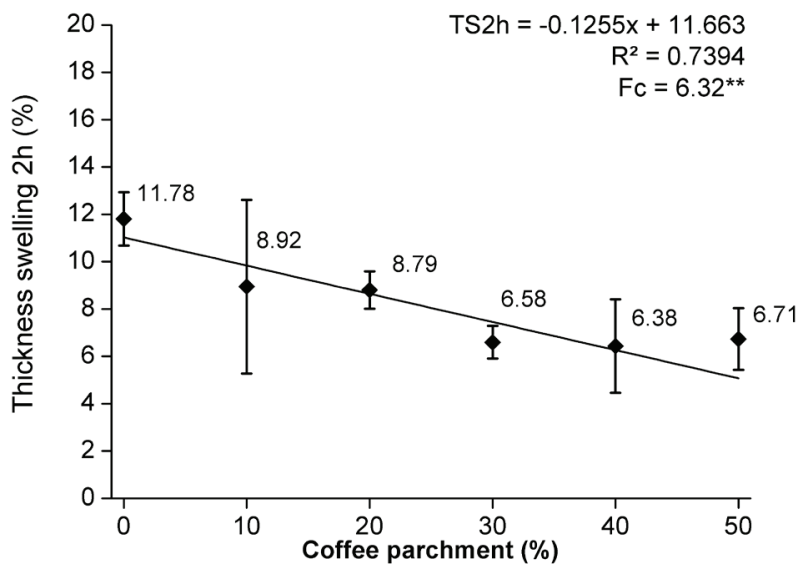

Figure 3: Mean values of TS2h as a function of coffee parchment percentage in panels.

**Significant F-value at 5\% significance level.

The TS2h of particleboards in this study ranged from 11.78 to $6.77 \%$. Somehow, the addition of coffee parchment in particleboards caused a decreasing trend in values of thickness swelling. This was assumed to be due the higher extractives amount present in coffee parchment, which decreased the hydrophilic characteristics of the particleboards produced with higher contents of the waste.

Decreases in TS2h trend with increases in the proportion of alternative biomass mixed with wood for particleboard production have already been reported in the literature. The authors found mean value for TS2h of $25.33 \%$ in particleboards composed by $50 \%$ pine wood and
$50 \%$ maize cob (Scatolino et al., 2013), which was higher than $50 \%$ coffee parchment obtained in this study. The low density of panels implies in lower content of particles for absorbing water, therefore the panels produced in this study showed lower values for physical properties in comparison to panels showing medium density found in the literature.

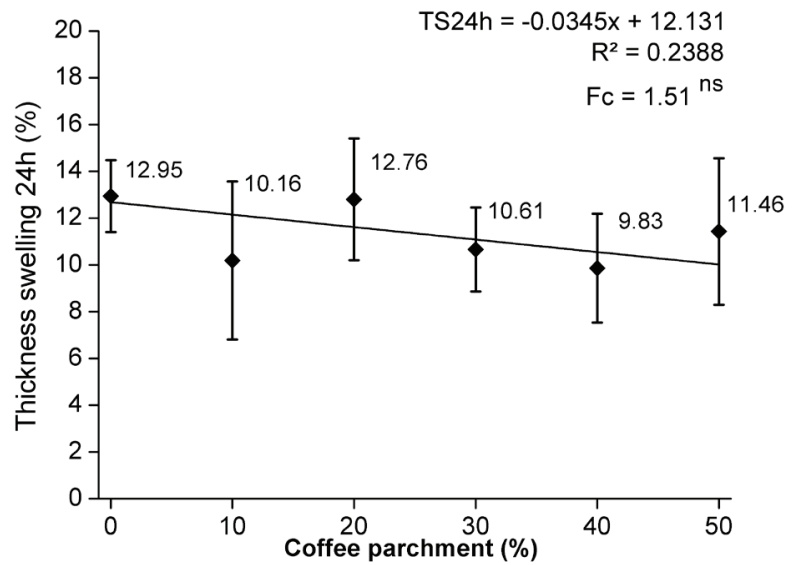

Figure 4: Mean values of TS24h as a function of coffee parchment percentage in panels.

**Significant F-value at 5\% significance level.

In other hand, the addition of coffee parchment on particleboards showed no significant effect on values of TS24h. None of the treatments exceeded the requirement for TS24h (30\%) considering low density panels by standard CS 236-66 (CS, 1968).

The physical properties were improved with the addition of coffee parchment to the particleboards. In addition to the extractives content, another relevant point was the increasing in compaction ratio (See table 3), which can promote a barrier for water adhesion. However, high values of compaction ratio means a lower amount of adhesive per particle, due the low density of the coffee parchment. This fact may affect the mechanical properties of panels. The linear regression models obtained for MOE and MOR were significant $(p \leq 0.05)$ such as the second order polynomial regression obtained for IB. The results are illustrated in Figures 5, 6 and 7.

The MOE values showed decreasing trend according to the linear regression model. The MOR values of particleboards produced in this study ranged from 8.16 to $4.42 \mathrm{MPa}$. As similarly occurred for MOE, a higher content of coffee parchment associated to eucalyptus wood seem to reduce significantly the MOR values. IB showed an increasing trend until the content of $30 \%$ 
coffee parchment. From this point on, the values started to decline. Güler and Buyüksari (2011) found values close to $0.16 \mathrm{MPa}$ for internal bond when evaluating particleboards produced with peanut husk. The IB strength is an indicator of the cohesion of the panel in the direction perpendicular to the plane of the panel (Andre et al., 2008).

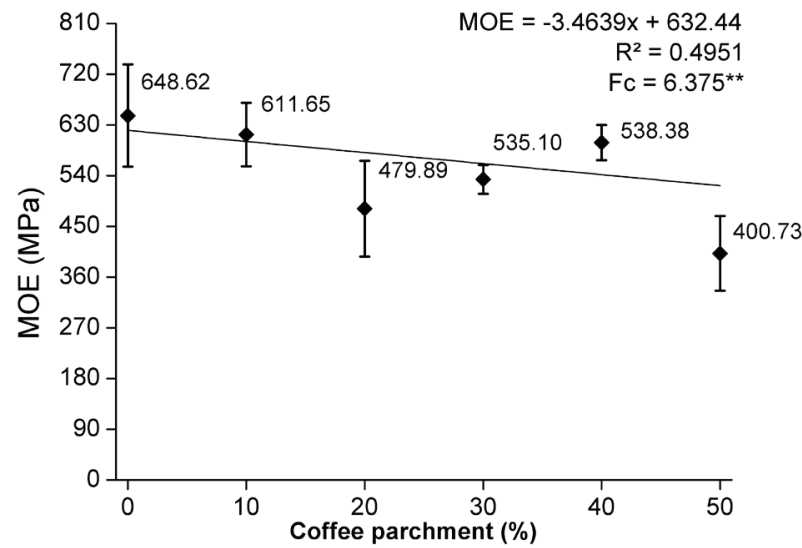

Figure 5: Mean values of MOE as a function of coffee parchment percentage in panels.

**Significant F-value at 5\% significance level.

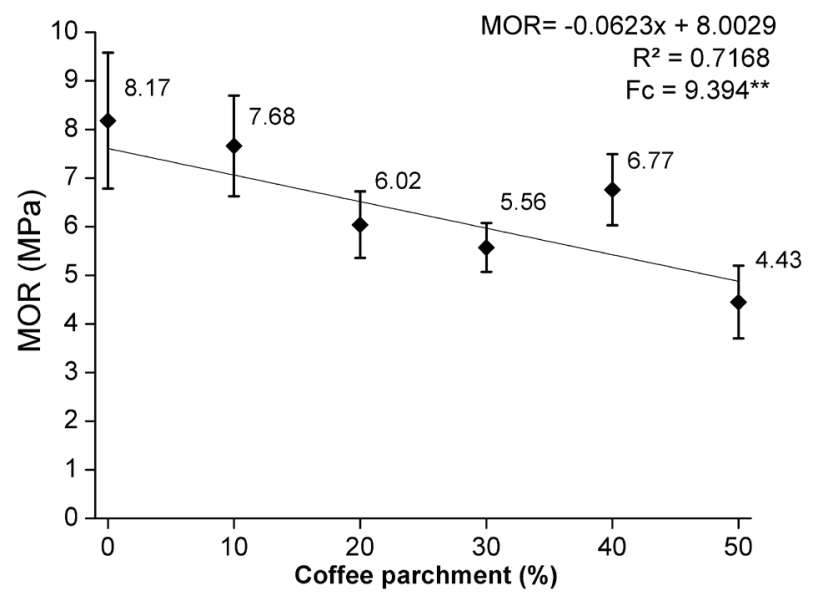

Figure 6: Mean values of MOR as a function of coffee parchment percentage in panels.

**Significant F-value at 5\% significance level.

The reason for decreasing of MOE and MOR values, such as seen for IB (40 and 50\% coffee parchment) may be related to the increase of compaction ratio. As previously explained, higher compaction ratio (See Table 3) implies a higher quantity of particles for being bonded with the same amount of adhesive, resulting in a lower amount of adhesive per particle.

Decreases in MOE and MOR trend with increases in the proportion of agricultural wastes mixed with wood for particleboard production have already been reported in the literature (Mendes et al., 2010; Scatolino et al., 2013). Güler and Buyüksari (2011) found values close to 2.90 MPa for MOR and 571.20 for MOE when evaluating low density particleboards produced with peanut husk. Sekaluvu, Tumutegyereize, and Kiggundu (2014) evaluated low density particleboards composed by maize cob particles and found means of $10 \mathrm{MPa}$ for MOE and 0.6 MPa for MOR.

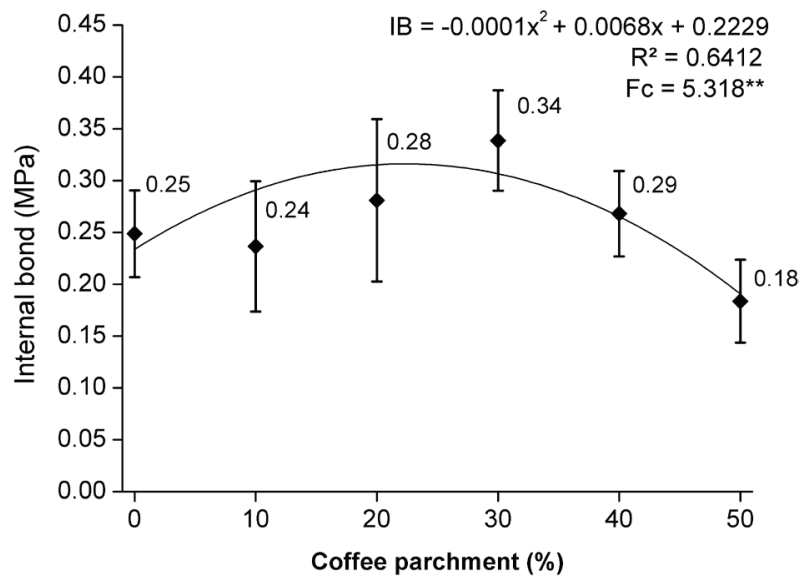

Figure 7: Mean values of IB as a function of coffee parchment percentage in panels.

**Significant F-value at 5\% significance level.

According to the commercial standard CS 236-66 (1968), the particleboards produced with urea formaldehyde adhesive and low density must provide minimum value of 5.5 MPa for MOR, which just was reached by 0,10 and $40 \%$ coffee parchment. For MOE, the same standard requires minimum of $1029.7 \mathrm{MPa}$, which has not been reached by any of the treatments produced. However, the particleboards composed by 0,10 and $40 \%$ of waste meet the minimum required by ANSI A208 (1999), which is $550 \mathrm{MPa}$. All values for IB were higher than the minimum required by the standard CS 236-66 (0.14 MPa), for low density panels.

\section{CONCLUSIONS}

Coffee parchment significantly improved the physical properties of WA and TS of particleboards. 
The panels composed by $40 \%$ coffee parchment showed better physical properties. The panels had significant decreases in mechanical properties MOR and MOE, however the values meet the minimum required by standards such as IB. Overall, there was a loss of mechanical strength of particleboard with coffee parchment addition. By the values of physical and mechanical properties, it can be concluded that the coffee parchment in association to eucalyptus wood for production of particleboard was viable with addition until $10 \%$, since these panels have reached the minimum of mostly standards. This waste can be used as alternative renewable raw material and promising to the declining wood supply in Brazil.

\section{ACKNOWLEDGEMENTS}

The authors thank to Fundação de Amparo à Pesquisa do Estado de Minas Gerais - FAPEMIG. Coordenacão de Aperfeiçoamento de Pessoa de Nível Superior - CAPES. Conselho Nacional de Desenvolvimento Científico e Tecnológico - CNPq, Brazilian Research Network in Lignocellulosic Composites and Nanocomposites RELIGAR and PPGBiomat - Programa de Pós-Graduação em Engenharia de Biomateriais.

\section{REFERENCES}

AMERICAN NATIONAL STANDARD PARTICLEBOARD - ANSI A208.1 Particleboard. 1999. 11p.

AMERICAN SOCIETY FOR TESTING AND MATERIALS ASTM D 1037. Standard Test Methods for Evaluating Properties of Wood-Base Fiber and Particle Panel Materials. 2006.

ANDRÉ, N. et al. Prediction of internal bond strength in a medium density fiberboard process using multivariate statistical methods and variable selection. Wood Science and Technology, 42(7):521-534, 2008

BELINI, U. L. et al. Multilayer panel with bamboo particles reinforcement. Scientia Forestalis, 42(103):421-427, 2014.

BRAZILIAN ASSOCIATION OF TECHNICAL STANDARDS - ABNT NBR 13999: Paper, board, pulps and wood - Determination of residue (ash) on ignition at $525^{\circ} \mathrm{C}$. Rio de Janeiro. 2003b. $4 \mathrm{p}$.

BRAZILIAN ASSOCIATION OF TECHNICAL STANDARDS - ABNT - NBR 14810: Medium density particleboards Part 2: Requirements and test methods. Rio de Janeiro. 2013.69p.

BRAZILIAN ASSOCIATION OF TECHNICAL STANDARDS - ABNT - NBR 14853: Determination of soluble matter in ethanol- toluene and in dichloromethane and in acetone. Rio de Janeiro. 2010a. 3p.

BRAZILIAN ASSOCIATION OF TECHNICAL STANDARDS - ABNT NBR 7989: Pulp and wood - Determination of acid-insoluble lignin. Rio de Janeiro. 2010b. 6p.

BRAZILIAN ASSOCIATION OF TECHNICAL STANDARDS - ABNT NBR 11941: Wood - Determination of basic density. Rio de Janeiro. 2003a. 6p.

BRUM, S. S. et al. Preparation and characterization of activated carbon produced from coffee waste. Quimica Nova, 31(5):1048-1052, 2008.

COMMERCIAL STANDARD - CS 236-66: Mat formed wood particle board. 1968.

FARRAPO, C. L. et al. Utilization of Pterocarpus violaceus wood in the particleboard production. Scientia Forestalis, 42(103):329-335, 2014.

FOOD AND AGRICULTURE ORGANIZATION OF THE UNITED NATIONS - FAO (2013). Available in: <http://faostat3.fao. org/browse/Q/QC/E>. Access in: 29 Aug. 2016.

GULER, C.; BUYUKSARI, U. Effect of production parameters on the physical and mechanical properties of particleboards made from peanut (Arachis hypogaea L.) husk. BioResources, 6(4):5027-5036, 2011

GULER, C.; OZEN, R. Some properties of particleboards made from cotton stalks (Gossypium hirsitum L.). Holz Roh Werkst, 62(1):40-43, 2004.

HARDELL, H. L.; NILVEBRANT, N. O. A rapid method to discrimination between free and esterified fatty acids by pyrolytic methylati on using tetramethyl ammonium acetate or hydroxide. Journal of Analytical and Applied Pyrolysis, 52(1):1-14, 1999.

IWAKIRI, S. Painéis de madeira reconstituída. Curitiba: UFPR, 2005, 274p.

MALONEY, T. M. Modern particleboard and dry-process fiberboard manufacturing. San Francisco: Miller Freeman, 1993.

MATI-BAOUCHE, N. et al. Mechanical, thermal and acoustical characterizations of an insulating bio-based composite made from sunflower stalks particles and chitosan. Industrial Crops and Products, 58(1):244250, 2014

MELO, R. R. et al. Properties of wood and rice husk particleboard in different proportions. Ciência Florestal, 19(4):449-460, 2009. 
MENDES, R. F. et al. Effect of the incorporation of coffee husks on the physico-mechanical properties of Eucalyptus urophylla S. T. Blake particleboards. Ciência e Agrotecnologia, 34(3):610-617, 2010.

MENDES, R. F. et al. Association effect of sugar cane bagasse, type and levels of adhesive on particleboard production. Ciência Florestal, 22(1):161-170, 2012.

MENDES, R. F. et al. Quality of homogeneous particleboard produced with Eucalyptus Urophylla clone wood. Cerne, 20(2):329-336, 2014.

NEUTELINGS, G. Lignin variability in plant cell walls: Contribution of new models. Plant Science, 181(4):379 -386, 2011.

NORMEN FUR HOLZFASERPLATEN SPANPLATTEN SPERRHOLZ DIN 52362: Testing of wood chipboards bending test, determination of bending strength. 1982.

PAULA, L. E. R. et al. Produção e avaliação de briquetes de resíduos lignocelulósicos. Pesquisa Florestal Brasileira, 31(66):103-112, 2011.

PAPADOPOULOU, E. et al. Value-added industrial products from bast fiber crops Industrial Crops and Products, 68(1):116-125, 2015.
SCATOLINO, M. V. et al. Maize cob utilization in particleboards production. Ciência e Agrotecnologia, 37(4):330-337, 2013.

SCATOLINO, M. V. et al. Thermal stability of Pinus oocarpa and maize cob particleboards. Ciência e Agrotecnologia, 39(4):348-354, 2015.

SEKALUVU, L.; TUMUTEGYEREIZE, P.; KIGGUNDU, N. Investigation of factors affecting the production and properties of maize cob-particleboards. Waste and Biomass Valorization, 5(1):27-32, 2014.

SILVA, D. W. et al. MDP with particles of eucalyptus and corn straw. Scientia Forestalis, 43(108):853-862, 2015.

SILVA, D. W. et al. Addition of different proportions of castor husk and pine wood in particleboards. Waste and Biomass Valorization, 7(34):1-7, 2016.

VILELA, F. G. et al. Use of sticky coffee hull for feeding of steers in feedlots. Ciência e Agrotecnologia, 25(1):198-205, 2001.

YENIOCAK, M. et al. Investigating the use of vine pruning stalks (Vitis Vinifera L. CV. Sultani) as raw material for particleboard manufacturing. Wood Research, 59(1):167176, 2014. 